\title{
Nordic journalists' conceptual roles and perceived influences
}

\author{
A European and inter-Nordic comparison
}

\author{
Jan Fredrik Hovden ${ }^{I}$ \& Jari Väliverronen ${ }^{\mathrm{II}}$ \\ I Department of Information Science and Media Studies, University of Bergen, Norway \\ II Faculty of Information Technology and Communication Sciences, Tampere University, Finland \\ Authors have contributed equally
}

\begin{abstract}
In this article, we comparatively explore Nordic journalists' perceived roles and influences on their work using survey data from the Worlds of Journalism project (2012-2016). In a European context, a principal component analysis of 18 Western and Southern European countries $(N=10,254)$ finds that Nordic journalists generally resemble journalists in other democratic corporatist countries, particularly by their relatively low experience of political and economic influences. Restricting the analysis to the Nordic countries $(N=3,246)$ finds that Swedish and Danish journalists stand out by their stronger adherence to monitorial roles. By their weaker attachment to political roles and weaker experience of political influences, Icelanders differ from Finns, with Norwegians in an intermediate position. The large intranational variation in both analyses suggests that in addition to media systems and national contexts, the role of different beats and positions within news organisations is crucial for understanding journalists' perceived roles and felt influences.
\end{abstract}

Keywords: Nordic journalists, journalistic roles, perceived influences, media systems, comparative analysis

\section{Introduction}

Much of the existing comparative journalism research on the Nordic countries falls into one of two main categories. The first category highlights the region's unique and uniform nature in a broad geographical setting. The Nordic countries are distinct from other parts of the (Western) world in their media systems, forming the Nordic model (Brüggemann et al., 2015) within the democratic corporatist system (Hallin \& Mancini, 2004). In the Nordic model, journalists' positions and values have developed closely alongside national political systems, with structural similarities and a strong belief in welfare state ideology (e.g., Brochmann et al., 2012; Lund \& Berg, 2009; Nord, 2008; Strömbäck et al., 2008; Syvertsen et al., 2014). This "welfare state of mind" remains a

Hovden, J. F., \& Väliverronen, J. (2021). Nordic journalists' conceptual roles and perceived influences: A European and inter-Nordic comparison. Nordicom Review, 42(1), 141-161 https:// doi.org/10.2478/nor-2021-0034 
shared feature of Nordic journalists' self-understanding, distinguishing them from other journalists globally (Ahva et al., 2017).

The second category of comparative journalism research on the Nordics concerns differences among the countries. Varying national developments in political systems and corporatism (Strøm \& Bergman, 2011), welfare state ideology (Kananen, 2014), and media systems (Nord, 2008; Ohlsson, 2015) have led to increasing variation between the Nordic countries (Skogerbø et al., 2021). Coupled with recent instability in journalism (e.g., Peters \& Broersma, 2013), these changes have affected the Nordic countries' conditions for journalism differently. In this research category, Iceland has emerged as an exception to the broader Nordic context (e.g., Guðmundsson \& Kristinsson, 2017). National-level studies into journalists' values and working conditions in the Nordics have also indicated variations between different groups of journalists (e.g., Albæk et al., 2015; Asp, 2012; Hovden, 2008; Pöyhtäri et al., 2016; Skovsgaard \& Van Dalen, 2013; Väliverronen, 2018).

Thus, consistent with most comparative studies (see, e.g., Hanitzsch et al., 2019; Weaver \& Willnat, 2012), research results on Nordic journalism depend on the measures and level of observation used. Considerable gaps remain in the literature - not least due to many previous studies' poor comparability. In this article, we address these issues using the Worlds of Journalism Study (WJS). The largest comparative journalism study ever conducted, its second wave (2012-2016) covered 67 countries around the world, including all Nordic countries. Although slightly dated, the data make it possible to observe for the first time similarities and differences in what Nordic journalists consider to be important roles and influences in their work - and how they compare internationally. The latter, focusing on the European context, forms the first part of our empirical analysis, while differences between the Nordic journalists form the second part. In this way alone, the article fills a major gap in the comparative literature on Nordic journalistic systems. Second, studies of journalists' perceived roles and influences customarily conceptualise them as separate elements, seen through the lenses of role theory and levelof-influences approaches. Here, we add a field sociological approach and see them as integrated elements of journalistic styles (Bourdieu, 1998; Hovden, 2008), which helps our understanding of how such perceptions are simultaneously influenced by media systems and individuals' positions in national journalistic fields.

We begin with a brief literature review in which we first describe some previous studies of roles and influences in journalism before presenting some background on the Nordic countries' journalistic developments. After briefly overviewing our data and measures, we explore differences among journalists in 18 Western and Southern European countries before examining inter-Nordic differences and discussing our findings.

\section{Roles, influences, and journalistic styles}

Roles

Research into journalistic roles has traditionally been dominated by concepts from role theory (e.g., Weaver \& Wilhoit, 1986; Weaver, 1998) and inspired by approaches originating in anthropology, sociology, and psychology (e.g., Abbott, 1988; Linton, 1945; Moreno, 1964; Parsons, 1961/2007). Journalistic roles are viewed as crucial building blocks of journalistic professionalism: they help us understand where journalists locate 
themselves in society, how they build their professional identity, and how they fulfil their functions in practice (Hanitzsch \& Örnebring, 2019). Thus, studying journalistic roles entails studying both their discursive articulations (e.g., Hanitzsch et al., 2019) and practical enactments (e.g., Mellado, 2021), and the ways in which these are interwoven. Analytically, this focus has been divided into two distinct levels: role orientations and role performance (Hanitzsch \& Vos, 2017). In this article, following the WJS, we focus on journalists' discursive articulations of their role orientations.

Hanitzsch and Vos (2017) subdivide role orientations into normative and cognitive components. Normative roles refer to journalists' and other stakeholders' generalised expectations about the aspirations and ideals of journalism (Donsbach, 2012). In turn, cognitive roles indicate how individual journalists embrace and selectively internalise normative roles as a result of their occupational socialisation (Hanitzsch \& Örnebring, 2019). Like the WJS, we investigate journalists' cognitive roles.

Research on journalists' cognitive roles has made many distinctions (for a discussion, see Hanitzsch \& Örnebring, 2019: 111); the most influential is probably Weaver and Wilhoit's (1996) separation between disseminators, interpreters, adversaries, and populist mobilisers. A later reappraisal from the WJS's second wave (Hanitzsch et al., 2019) emphasised four cognitive roles that we use here: The monitorial role is grounded in ideas of journalism as the "Fourth Estate" and a critical correction to power. By contrast, in the collaborative role, journalists are partners to power (in particular, governments), promoting development and well-being. The interventionist role relates to journalists' engagement in social affairs and self-perceptions as participants in political life. The accommodative role concerns audiences as consumers - for instance, through journalists providing entertainment and life advice.

\section{Influences}

As noted, journalistic roles are influenced by a complex interplay between journalists and other actors and factors. These different influences have been researched extensively. Similar to journalistic roles, studies have indicated several competing classifications. Early models (e.g., Ettema et al., 1987) distinguished between individual, organisational, and institutional influences. Later, Shoemaker and Reese (1996) introduced the hierarchy-of-influences model, in which journalists' influences range from social systems, institutions, organisations, and routine practices to individual factors. It is still one of the most widely used classifications and particularly useful in comparative studies. Debate around it concerns mainly the relative strength of different influences and journalists' ability to distinguish them (Hanitzsch et al., 2019).

This debate is a key reason why another distinction has been made between actual and perceived influences; they must be distinguished here since perceived influences are what we can measure via questionnaires. The WJS project operationalised five domains of perceived influence that we also adhere to: political (e.g., pressure from politicians), economic (economic and commercial pressures), organisational (structures governing media organisations' decision-making, for example, editorial pressure), procedural (everyday constraints, for example, lack of time and resources), and personal (interactions with other people, for example, peers and family). For a detailed discussion of these concepts, the associated indexes, and national differences, see Hanitzsch and colleagues' work (2019). 


\section{Journalistic styles}

Previous research has mainly studied perceptions of roles and of influences separately (e.g., Ahva et al., 2017; Hanitzsch et al., 2019), but these are obviously connected. For example, political journalists often emphasise the monitorial and interventionist roles (Skovsgaard \& van Dalen, 2013) and feel notable influences from the political system (Maurer, 2019). Such influences, however, vary across countries (van Dalen, 2012). To integrate journalists' perceptions of roles and influences in a common interpretative framework, we will use the concept of journalistic style, a specific variant of professional styles inspired by the sociological concept of lifestyles (Bourdieu, 1984; Weber, 1978). Lifestyles refer to the totality of practices, habits, and orientations of individuals. They are not restricted to people's private lives: the distinction between private and professional - which forms the basic ideology of professionalism - is not very meaningful in Bourdieu's anthropological and bodily sociology, which emphasises the unitary nature of habitus and practice (Hovden, 2008).

The concept of journalistic style, in contrast, designates those parts of journalists' lifestyles particularly relevant to their professional practice - for example, ways of using language, feelings of self-confidence or where they belong in the world, what they find interesting, and so forth. While journalists incorporate in their habitus the "primary socialisation" and trajectory which have formed their overall lifestyle, their journalistic style is also marked by a "secondary socialisation" into a partly autonomous cultural realm, which over time has developed its own norms and hierarchies - the national journalistic field. This field exerts a "censoring effect" on acceptable practices and thoughts, with sub-fields offering their own minor variations of this culture. Like overall lifestyles, journalistic styles are not simply expressions of incorporated inclinations (dispositions), but simultaneously rooted in journalists' positions given by their specific resources (capital) valuable in the relevant context, in this case, the field(s) of journalism - for instance, editorial power and peer recognition (Hovden, 2008).

In regard to journalists' perceived influences, we expect their position to be expressed through specific limitations in their work - for example, in their autonomy to select stories, available time, and their need to aim for the largest possible audience. Higher positions do not necessarily mean fewer outside influences, as working in the most prestigious forms of journalism also means coming into contact and conflict with the elites of other social fields, such as political and business elites. Journalists' perceived roles are similarly expected to be related to both their positions and dispositions. For example, an educational orientation towards audiences might be rooted both in specific norms related to the beat (true for cultural journalism in most of the world, see Hovden \& Kristensen, 2018) and in more general dispositions (e.g., high cultural capital accumulated through a privileged upbringing or through specific studies unrelated to journalism). At the same time, we expect that the varying media systems and national overall cultures constitute different contexts for journalists, with consequences for perceived roles and influences.

\section{Nordic journalistic roles and influences}

For the Nordic countries, the historical and political contexts are quite similar (Bergman \& Strøm, 2011), including their media. They share a democratic corporatist media system based on a close relationship between journalism and politics (Hallin 
\& Mancini, 2004). Though the states differ, especially Iceland (e.g., Harðarson, 2008; Olafsdottir \& Olafsson, 2014), their democratic corporatist developments have been largely uniform. Their journalism heavily relied and focused on political parties until the 1950s (Strömbäck et al., 2008). Since the 1960s, the party press has declined (Nord, 2008) and journalism's focus and dependence shifted to the state. During this shift, public service broadcasting assumed a major position in Nordic journalism (e.g., Djerf-Pierre \& Weibull, 2001; Salokangas, 1996), and journalists increased their professionalism and autonomy. In the 1980s and 1990s, Nordic journalism became more diverse and market oriented (Ekecrantz, 2005; Strömbäck et al., 2008). In the new century, changes in political communication (Skogerbø et al., 2021) and journalism's increasing market focus have affected Nordic countries' media systems slightly differently; they have become varying hybrids of democratic corporatism and liberalism (Nord, 2008; Ohlsson, 2015).

These developments also changed Nordic journalists' self-understandings and influences. In the first half of the twentieth century, journalists helped build welfare states (Syvertsen et al., 2014) and dutifully reported political elites' views (Strömbäck et al., 2008). Alongside their differentiation from political parties and increasing professionalisation, beginning in the 1960 s, journalists gradually assumed more active monitoring roles alongside reporting in the name of public service (Djerf-Pierre \& Weibull, 2001; Koljonen, 2013). As market influences grew, journalists further withdrew from politics in the 1990s, adopting an interpretative ethos (Djerf-Pierre \& Weibull, 2001; Koljonen, 2013; Strömbäck et al., 2008). These historically layered functions - reporting, monitoring, and explaining or interpreting - are generally strong in Nordic journalists' selfunderstanding at a national level. Alongside them, the rising market focus and diversity have increased variation in Nordic journalists' self-understanding, as well as their procedural and organisational influences (Albæk et al., 2015; Asp, 2012; Guðmundsson \& Kristinsson, 2017; Hovden, 2008; Kolbeins, 2017; Pöyhtäri et al., 2016).

Increasing country-level variation has not affected the long-held view of the Nordic countries as "most similar" systems (e.g., Miles, 1996) in international comparisons. Nordic media systems constitute one group - either a close-knit cluster within a broader system (Hallin \& Mancini, 2004) or a Nordic model distinct from Central European democratic corporatist countries (Brüggemann et al., 2015). Similarly, the global WJS analyses showed that Nordic journalists' perceived roles and influences were relatively homogenous. Their self-understanding strongly focuses on the monitorial role at the expense of interventionist, collaborative, and accommodative roles. They also perceive low political and economic influences (Hanitzsch et al., 2019). These views constitute a welfare state mentality that reflects the shared Nordic history in politics and the media (Ahva et al., 2017).

However, the global setting's significant media and political differences can easily conceal significant national and other differences (Hanitzsch et al., 2019). A focus on either roles or influences can similarly mask relevant differences. To avoid these problems, we use WJS data in this study, but examine the Nordic countries through European and inter-Nordic lenses, focusing on how perceived roles and influences are combined. 


\section{Data and method}

We analysed survey responses from journalists collected by the WJS project's national research teams in 67 countries, from 2012 to 2016. This data collection used extensive standardised surveys and field methodology. The survey defined a "journalist" as a person who earns at least $50 \%$ of their income from paid labour for news media and is involved in producing and editing journalistic content, as well as editorial supervision and coordination. In this article, we analyse two subsets of these data. First, the European analysis covers 18 countries in Europe's Nordic, Western, and Southern regions $(N=$ $10,254)$ to broadly contextualise Nordic journalists' perceived roles and influences. ${ }^{1}$ The second analysis is restricted to the five Nordic countries $(N=3,246)$ to discover finer internal differences which might be overlooked at a European level.

The Nordic survey data were collected in 2012-2015, with varying methods and response rates (see Table 1). Response rates were low for some countries, likely resulting in some notable skew in our samples. The Swedish sample appears the most problematic for our Nordic comparison; not only does it overrepresent older and daily-newspaper journalists, but it also used a pre-recruited online panel, an approach which literature finds to be generally less likely to provide accurate population measures than traditional random sampling (Baker et al., 2010). The Finnish sample is slightly biased towards executive managers, and also differs from Denmark, Iceland, and Norway - which all used random sampling based on union member lists. Finland used geographically stratified sampling to choose respondents' media outlets, and respondent quotas were disproportional because more than five respondents (the maximum quota envisioned by the WJS's central administration) were selected from some outlets due to a few outlets' heavy concentration of journalists in some media types (TV, radio, news agencies). The Norwegian sample - unlike the case for Denmark and Iceland - is biased towards editors and older journalists. Iceland's regional media, however, was slightly under-sampled. Although Denmark's response rate is the lowest among the countries, no particular biases in the sample have been identified. This discussion is based on country reports submitted by countries' coordinators; for a more detailed discussion of methodological challenges and representativity in the WJS, see the WJS project website's methodological documentation and Hanitzsch and colleagues' work (2019: 47-66).

Table 1 Nordic WJS sample methodology

\begin{tabular}{|c|c|c|c|c|c|}
\hline Country & $\begin{array}{c}\text { Year of } \\
\text { data } \\
\text { collection }\end{array}$ & Sample & Method & $\begin{array}{l}\text { Number of } \\
\text { respondents }\end{array}$ & $\begin{array}{l}\text { Response } \\
\text { rate }(\%)\end{array}$ \\
\hline Denmark & 2015 & All members of Journalism Union & Online & 1,362 & 19 \\
\hline Finland & 2013 & $\begin{array}{l}\text { Stratified sample (media type and } \\
\text { geographical location) of all journalists }\end{array}$ & $\begin{array}{l}\text { Mixed } \\
\text { (phone \& } \\
\text { email) }\end{array}$ & 366 & $50-55$ \\
\hline Iceland & 2012 & The whole population of journalists & $\begin{array}{l}\text { Mixed (face- } \\
\text { to-face } \\
\text { \& online) }\end{array}$ & 187 & 53 \\
\hline Norway & 2013 & $\begin{array}{l}\text { All members of Union of Journalists and } \\
\text { Union of Editors }\end{array}$ & Online & 656 & 36 \\
\hline Sweden & 2013-14 & Members of online Journalist Panel & Online & 675 & 36 \\
\hline
\end{tabular}




\section{Measures}

In assessing journalists' role conceptions, the WJS project took inspiration from earlier cross-cultural studies (e.g., Weaver, 1998; Weaver \& Willnat, 2012) and devised a battery of 18 roles, asking how important each was in journalists' work (e.g., being a detached observer, monitoring political leaders, providing entertainment). Answers used a five-step Likert scale ( 1 = unimportant, $5=$ extremely important). Journalists' perceived influences on their own work were measured by 25 different actors and factors (e.g., owners, time limits, on-staff peers), and responses ranged from 1 (not influential) to 5 (extremely influential). Three additional role variables and two source-of-influence variables were optional questions in the WJS questionnaire; since few countries addressed them, they were excluded from our analysis. These 43 variables (transformed to numeric form) constituted the active variables in the following analyses. Each question's averages and standard deviations are provided for each country by Hanitzsch and colleagues (2019) and on the WJS website. Figure 1 provides an overview of the 18 countries' average scores in the global WJS analysis, using four indexes for roles and five for influences (Hanitzsch et al., 2019).

Figure 1 Indexes for perceived roles and influences for European journalists
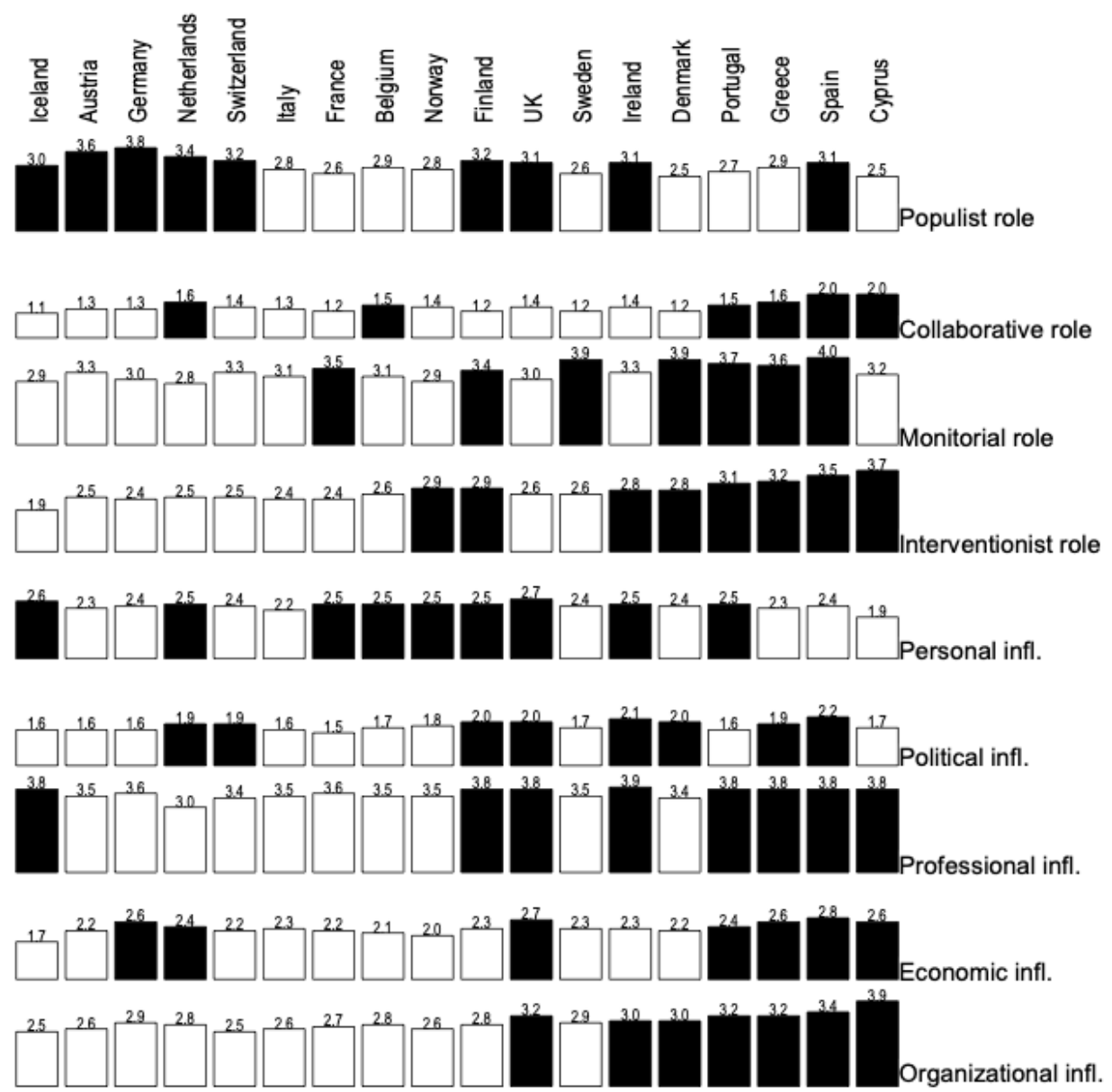

Comments: Bertin graph with country means for perceived roles and influences. 18 countries, $N=10,254$. Black categories are above-average for the variable. 
We then added additional measures as supplementary variables to help interpret and suggest underlying important factors. These include the aforementioned indexes and an additional index of journalists' perceived editorial autonomy, the latter combining responses to two questions regarding journalists' freedom to select news stories and decide which aspects of a story to emphasise. Furthermore, we added various indicators of journalists' backgrounds and positions - including country, social background, experience, position within an organisation, beat, and media type. Note that our statistical analyses were completely blind to these indicators - including country - when examining differences between journalists.

\section{Method}

As we argue, perceived roles and influences can be regarded as two related elements of journalistic styles. This conceptual argument is supported by the strong correlation between journalists' answers to the two sets of questions (the first three canonical coefficients explained $65 \%$ of the common variance among the two variable sets for the selected European countries and $53 \%$ of the variance for Nordic countries only). We weighted the dataset to firstly equally weight each country - regardless of sample size - and secondly assign both sets of variables equal importance, adjusting for their unequal number of questions. ${ }^{2}$ Normed principal component analysis (PCA) was used to examine journalists' main differences in perceived roles and influences. To cluster journalists based on their positions in the Nordic space following the PCA, we used hierarchical agglomerative (consolidated) clustering of the top components (selected by Kaiser criteria - i.e., eigenvalues over averages). In the following, we present the main results, and the Supplementary Material file provides more detailed information on all analyses conducted.

\section{Nordic journalists in a European context}

Our first analytical question regarded Nordic journalists' general position in a European context. We asked: What main differences in perceived roles and influences divide European journalists? Are journalists in the Nordic countries typically more similar to each other than journalists in other countries, and which other countries are they most similar to? Our PCA analysis of the 18 studied countries suggests two main divisions (henceforth, axes), explaining 26 per cent of the variance. Table 2 shows the main characteristics of this analysis, together with correlations for selected indexes.

We illustrate the main differences and selected categories in a PCA map (see Figure 2), a two-dimensional, imperfect representation of a complex high-dimensional space of statistical relationships between individuals and variables. The closer individuals place to each other on the map, the more similar their overall response patterns generally are. Similarly, the closer to each other variables are, the higher their correlation typically is. The first (horizontal) axis is the line of differences between individuals, which explains most of the variance in the underlying table, the second (vertical) axis explains most of the remaining variance, and so forth. Our analysis suggests that European journalists are divided firstly according to their levels of detachment from various journalistic roles and outside influences, and secondly by their varying emphases on democratic-deliberative roles versus more 
Table 2 Principal component analysis of journalists in 18 European countries

\begin{tabular}{lccrr}
\hline & Axis 1 & Axis 2 & Axis 3 & Axis 4 \\
\hline Eigenvalue & 6.38 & 4.69 & 2.77 & 2.37 \\
\% of explained variance & 14.9 & 10.9 & 6.4 & 5.5 \\
Cumulated \% & 14.9 & 25.8 & 32.2 & 37.8 \\
\hline \multicolumn{5}{c}{ \% of contribution to axes } \\
\hline Roles & 51.5 & 61.0 & 66.0 & 45.8 \\
Influences & 48.5 & 39.0 & 34.0 & 54.2 \\
\hline \multicolumn{5}{c}{ Correlation } \\
& with indexes & & \\
\hline Monitorial & 0.57 & -0.70 & -0.11 & -0.05 \\
Interventionist & 0.68 & -0.31 & 0.42 & -0.01 \\
Collaborative & 0.48 & 0.07 & 0.50 & -0.13 \\
Populist & 0.26 & 0.35 & 0.44 & 0.48 \\
Political & 0.61 & 0.30 & -0.24 & -0.54 \\
Organisational & 0.49 & 0.40 & -0.10 & 0.14 \\
Procedural & 0.46 & 0.05 & -0.49 & 0.33 \\
Economic & 0.44 & 0.50 & 0.08 & 0.19 \\
Personal & 0.39 & 0.37 & -0.18 & 0.10 \\
Autonomy & -0.04 & -0.16 & 0.05 & 0.16 \\
\hline
\end{tabular}

Comments: 18 countries $(N=10,254)$.

Figure 2 Perceived roles and influences (European variations)

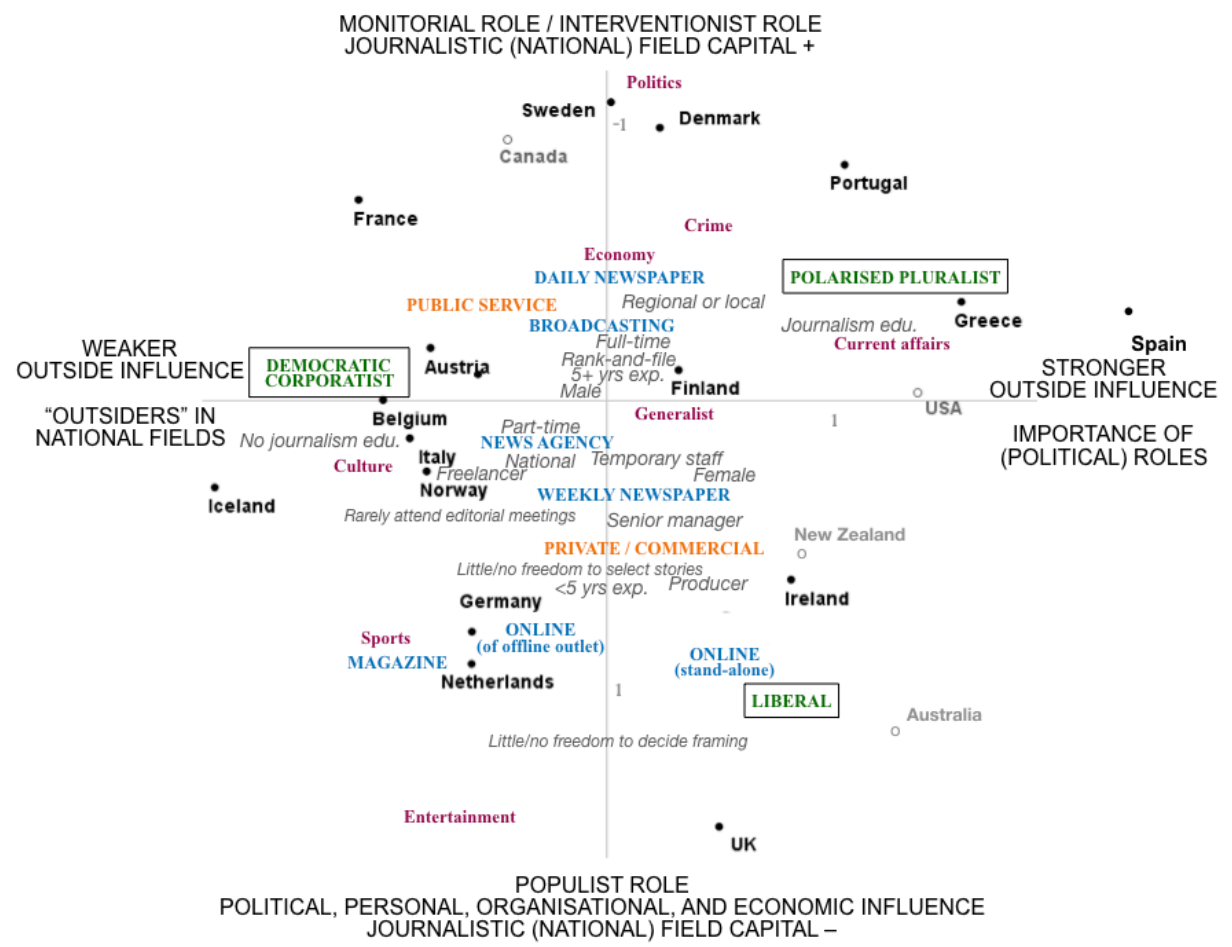

Comments: Map of the variations in perceived roles and influences among journalists in 18 European countries. Principal component analysis, Axis 1-2. Active and passive categories. Non-European liberal countries added for reference.

Source: Authors 
accommodating roles and market-related influences. Nordic journalists appear - in line with Ahva and colleagues (2017) - to be generally characterised by stronger-than-average feelings of insulation from both political and economic constraints and expectations.

Along the horizontal axis, European journalists are divided by their general agreement with the importance of the listed roles and influences in their work. Understanding journalists' answers, however, necessitates taking into account not only differences in the countries' media systems and political systems, but also individual journalists' positions in their national journalistic fields and media organisations. At country level, the axis especially divides journalists in questions related to the political system (e.g., feeling influence from politicians or adhering to a monitorial role is less common for those on the left). This highlights the central position of national political systems for understanding differences in national journalistic cultures. In line with the framework by Hallin and Mancini (2004), democratic corporatist countries generally place differently from polarised pluralist countries - though not always (e.g., France and Italy place closer to the former). Countries placing towards the left of this axis also tend to score positively on indexes of democratic development and press freedom (Hanitzsch et al., 2019), and journalists in these countries express less precariousness from job insecurity, owners' whims, or political pressures. Within countries, however, freedom from politicians and powerful groups often means something more negative - an outsider status, a distance from the symbolic centre of "real" journalism, and lack of journalistic capital (see Neveu, 2002; Hovden, 2008). This can be seen, for example, by how journalists placing towards the left typically work on "soft" beats - for instance, cultural or sports journalists groups which typically not only score low on political roles and influences (Hovden \& Kristensen, 2018), but also have low recognition from journalistic peers (Hovden, 2008).

The vertical axis emphasises other divisions. Journalists at the lower part of this axis reported weak editorial autonomy and strong outside influences on their work, particularly from economic factors (advertising, public relations, profit expectations). They emphasised interventionist and monitorial roles very little and highlighted the populist disseminator role instead. Along this axis, journalists from liberal media systems (the UK, Ireland) generally placed lower than journalists in democratic corporatist (Sweden, Denmark) or polarised pluralist (Spain, Greece, France) systems. In terms of backgrounds and work situations, this axis differentiates journalists' general positions in their field. It contrasted less- versus more-powerful and secure positions, younger versus older journalists, a lack of versus access to higher education (and journalistic specialisations), part-time versus full-time employment, online or magazine versus traditional journalism, and "soft" versus "hard" beats. ${ }^{3}$

In a European context, then, Nordic journalists generally appear to be quite similar to journalists in other Western European countries - especially in regard to their low perceived political and economic influences on their work. They also appear more similar to journalists in other democratic corporatist media systems than to journalists in polarised pluralist and liberal systems (see Figure 3). In this way, our results support the importance of media systems for understanding journalistic cultures. It must be noted, though, that the results show significant intranational variation. ${ }^{4}$

Distinct inter-Nordic differences also appeared in our results. Swedish and Danish journalists are characterised, on average, by stronger monitorial ideals. Icelandic and Norwegian journalists, in contrast, appear more detached from political roles and con- 
Figure 3 Media systems and perceived roles and influences

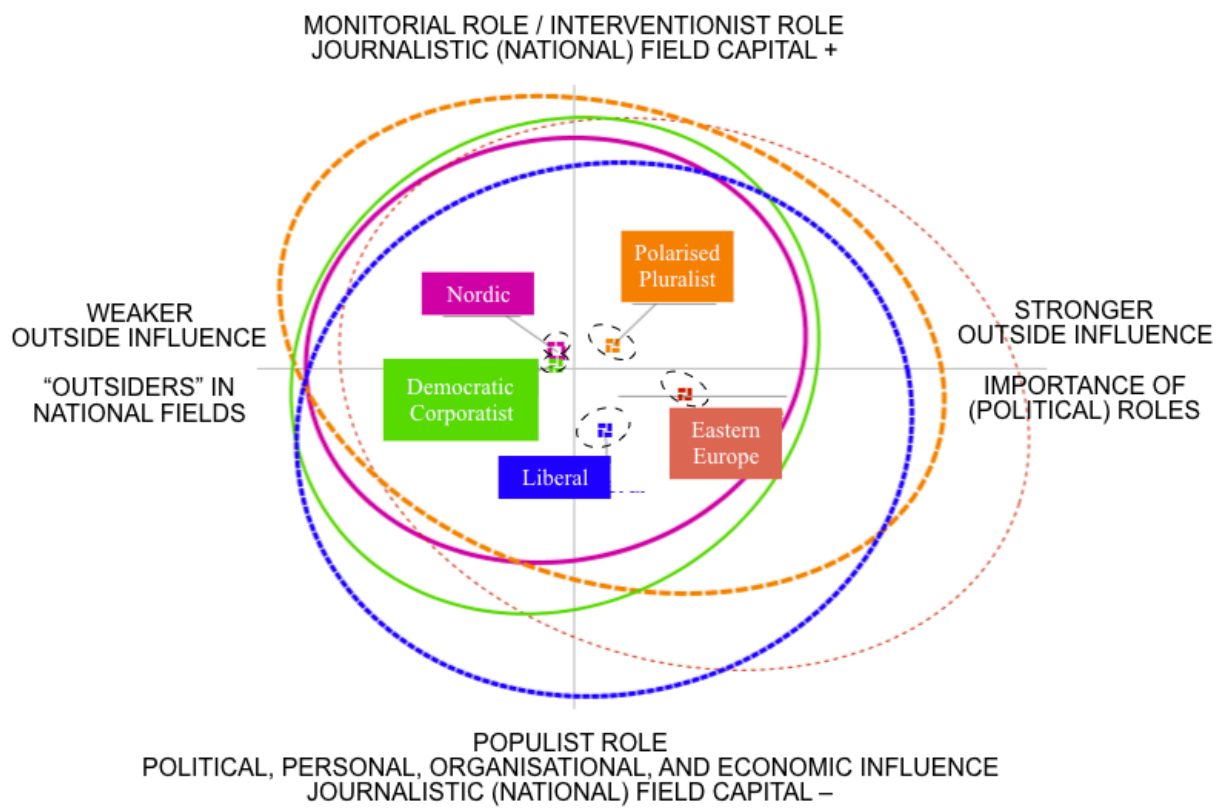

Comments: The figure shows the relative placement and spread of journalists from different media systems in the space of European differences in perceived roles and influences. Principal component analysis, axes 1-2: Concentration and confidence ellipses for Hallin and Mancini's (2004) media systems; Eastern Europe added for reference. The five small confidence ellipses show the uncertainty in the different media systems' positions. These ellipses' separation indicates their significantly different positions on the plane. The five big concentration ellipses show individuals' spread. A normally shaped cloud contains $86 \%$ of the individuals in a category.

Source: Authors

straints than Finnish journalists. These differences on a European scale, however, might conceal finer Nordic differences, which will be the focus in the following analysis.

\section{Nordic variations}

The second analysis repeats the PCA analysis above for the Nordic countries only. As we can see in Table 3, the main differences among Nordic journalists are variations of the patterns we found for Europe, generally emphasising the same differences and showing a similar explanatory power. Nordic journalists are, like European journalists overall, firstly divided by the perceived general importance of outside influences and roles on their work (the horizontal axis in Figure 4). Norwegian and Icelandic journalists generally felt the least constrained by these factors. Again, these differences appear mostly related to the political system. In contrast to our European analysis, however, in the Nordics, this appears more strongly related to roles than influences, likely a reflection of Nordic countries' much greater similarity in media systems and political cultures. Danish, Swedish, and Finnish journalists particularly emphasised the monitorial and interventionist roles' importance. The first axis also similarly separates "hard" (particularly politics) versus "soft" (particularly culture) beats, local and regional versus national journalists, higher versus lower educational credentials, newspapers versus other media, and senior or permanent staff versus younger, part-time, and freelance workers. 
Jan Fredrik Hovden \& Jari Väliverronen

Table 3 Principal component analysis of Nordic journalists

\begin{tabular}{llllc}
\hline & Axis 1 & Axis 2 & Axis 3 & Axis 4 \\
\hline Eigenvalue & 5.63 & 4.03 & 3.01 & 2.59 \\
\% of explained variance & 13.1 & 9.4 & 7.0 & 6.0 \\
Cumulated \% & 13.1 & 22.5 & 29.5 & 35.6 \\
\hline \multicolumn{5}{c}{ \% of contribution to axes } \\
\hline Roles & 69.6 & 42.4 & 78.2 & 56.4 \\
Influences & 30.4 & 57.6 & 21.8 & 43.6 \\
\hline & Correlation & with indexes & & \\
\hline Monitorial & -0.72 & 0.53 & -0.18 & 0.10 \\
Interventionist & -0.67 & 0.14 & 0.53 & -0.13 \\
Collaborative & -0.32 & -0.11 & 0.52 & -0.06 \\
Populist & -0.16 & -0.41 & 0.14 & -0.62 \\
Political & -0.53 & -0.44 & -0.13 & 0.53 \\
Organisational & -0.37 & -0.37 & -0.01 & 0.00 \\
Procedural & -0.34 & -0.26 & -0.42 & -0.22 \\
Economic & -0.31 & -0.44 & 0.10 & -0.15 \\
Personal & -0.28 & -0.51 & -0.12 & 0.02 \\
Autonomy & 0.04 & 0.13 & -0.12 & -0.15 \\
\hline
\end{tabular}

Comments: Five countries $(N=3,246)$.

Figure 4 Perceived roles and influences (Nordic variations)

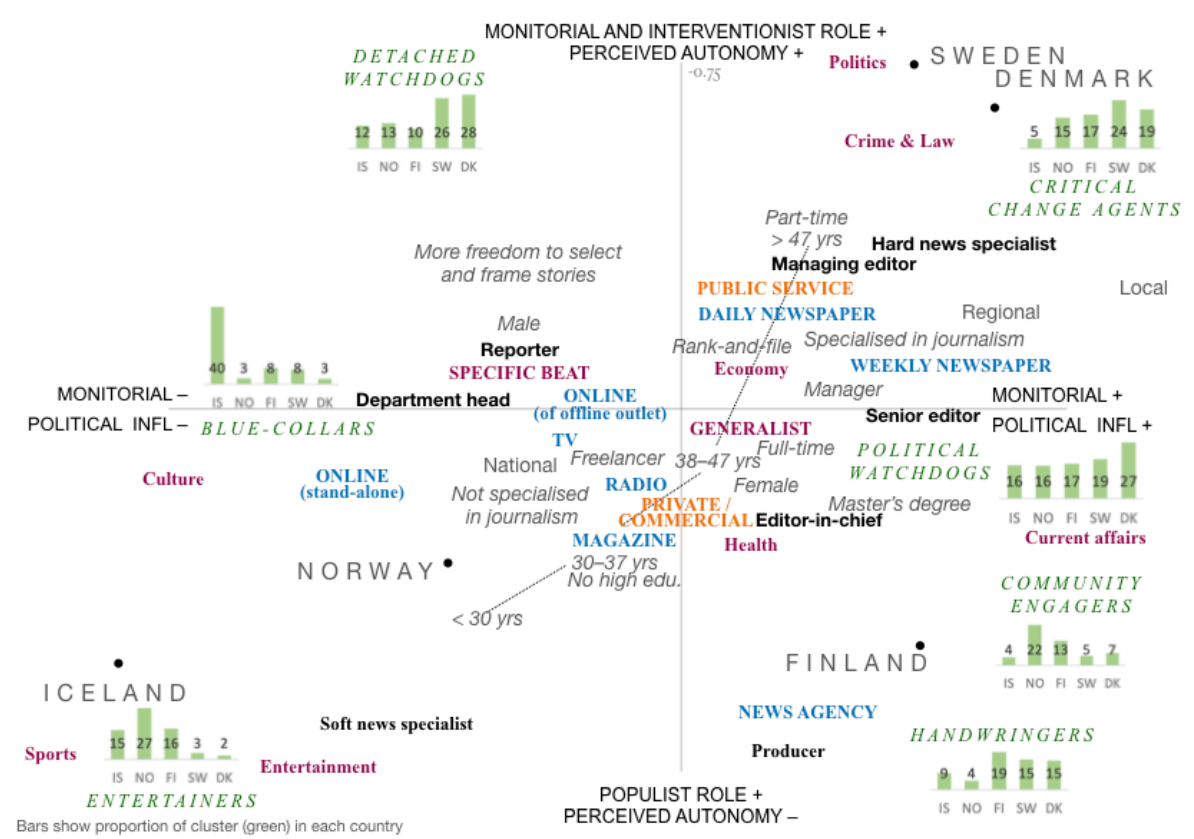

Comments: Map of the variations in perceived roles and influences among journalists in the Nordic countries.

Principal component analysis, Axis 1-2. Active and passive categories.

Source: Authors 
Nordic journalists are - like European journalists overall - divided by partiality towards the monitorial and interventionist roles' importance (more common among Swedish and Danish journalists) versus more accommodating (i.e., market-oriented) roles (the vertical axis in Figure 4). Again, Nordic differences were lesser than for Europe as a whole, and this second axis similarly separated journalists in higher versus lower editorial positions, and opposed "hard" beats like politics, economy, and crime against "soft" beats. It also divided journalists in public service from journalists in private or commercial outlets, as well as traditional newspaper and public service journalists from journalists in other media (particularly magazines and stand-alone online outlets). ${ }^{5}$ Male and female journalists were separated along both axes, suggesting female journalists' continuing subordination in Nordic journalism's symbolic and organisational orders (Djerf-Pierre, 2007; Hovden, 2008). This structure generally repeated within each national field, but again, there was considerable variation inside countries regarding perceived roles and influences (see Figure 5). Notably, social backgrounds (not least age, gender, and educational level) and working conditions of journalists vary substantially between the countries (see Table 4).

Figure 5 Nordic differences

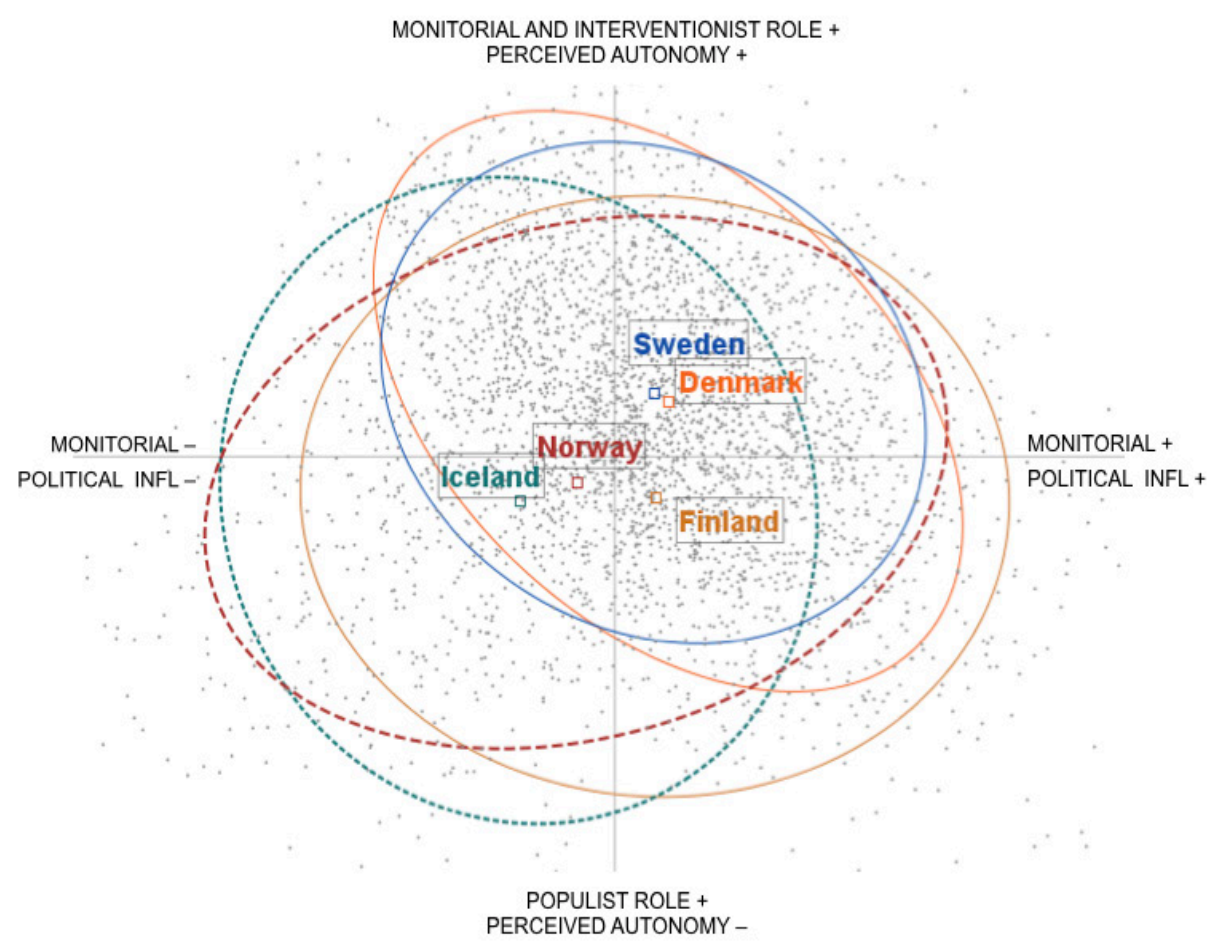

Comments: The figure shows the relative placement and spread of the five countries' journalists in the Nordic plane of perceived roles and influences. Principal component analysis, axes 1-2: Concentration and confidence ellipses. Five Nordic countries, $N=3,246$.

Source: Authors 
Jan Fredrik Hovden \& Jari Väliverronen

Table 4 Selected characteristics of Nordic journalists

\begin{tabular}{|c|c|c|c|c|c|c|}
\hline & Iceland & Norway & Finland & Sweden & Denmark & Total \\
\hline \multicolumn{7}{|c|}{ Reach } \\
\hline Local & 2 & 27 & 13 & 27 & 10 & 16 \\
\hline Regional & 6 & 22 & 27 & 32 & 20 & 23 \\
\hline National & 91 & 51 & 60 & 40 & 70 & 61 \\
\hline \multicolumn{7}{|c|}{ Ownership } \\
\hline Private & 75 & 81 & 77 & 72 & 68 & 73 \\
\hline Public & 25 & 19 & 23 & 28 & 32 & 27 \\
\hline \multicolumn{7}{|c|}{ Medium } \\
\hline Newspaper & 64 & 60 & 49 & 59 & 50 & 55 \\
\hline Magazine & 3 & 12 & 27 & 14 & 20 & 18 \\
\hline Broadcasting & 32 & 28 & 24 & 27 & 29 & 28 \\
\hline Online outlet or standalone & 3 & 2 & 1 & 0 & 8 & 4 \\
\hline \multicolumn{7}{|c|}{ Beat } \\
\hline Generalist & 72 & 65 & 52 & 38 & 59 & 56 \\
\hline News/current affairs & 1 & 1 & 11 & 0 & 1 & 2 \\
\hline Politics & 7 & 6 & 6 & 25 & 11 & 12 \\
\hline Economy & 5 & 3 & 3 & 6 & 4 & 4 \\
\hline Crime and law & 0 & 1 & 1 & 3 & 1 & 1 \\
\hline Culture & 3 & 9 & 5 & 6 & 5 & 6 \\
\hline Sports & 8 & 4 & 3 & 5 & 3 & 4 \\
\hline Health & 0 & 4 & 2 & 0 & 3 & 2 \\
\hline Entertainment & 0 & 2 & 1 & 2 & 1 & 1 \\
\hline Other & 5 & 6 & 16 & 16 & 11 & 11 \\
\hline \multicolumn{7}{|c|}{ Full-time, part-time, or freelance } \\
\hline Full-time & 90 & 73 & 78 & 74 & 71 & 74 \\
\hline Part-time & 5 & 5 & 4 & 7 & 5 & 5 \\
\hline Freelance & 5 & 23 & 18 & 18 & 23 & 21 \\
\hline \multicolumn{7}{|c|}{ Editorial rank } \\
\hline Senior/executive manager & 16 & 11 & 7 & 4 & 6 & 7 \\
\hline Junior manager & 15 & 6 & 20 & 18 & 23 & 18 \\
\hline Rank-and-file & 69 & 83 & 73 & 78 & 71 & 75 \\
\hline \multicolumn{7}{|c|}{ Experience } \\
\hline Less than 5 years & 24 & 15 & 7 & 2 & 12 & 10 \\
\hline 5 years or more & 76 & 85 & 93 & 98 & 88 & 90 \\
\hline Age (mean) & 39.6 & 43.3 & 43.4 & 51.3 & 45.9 & 44.7 \\
\hline
\end{tabular}


Table 4 Cont.

\begin{tabular}{lcccccc}
\hline & Iceland & Norway & Finland & Sweden & Denmark & Total \\
\hline Female & \multicolumn{7}{c}{ Gender } & & & & \\
Male & 35 & 50 & 55 & 46 & 43 & 46 \\
& 65 & 50 & 45 & 54 & 57 & 54 \\
\hline High school & 21 & Educational level & & & \\
Bachelor & 47 & 67 & 27 & 52 & 65 & 57 \\
Master's or higher & 32 & 25 & 61 & 35 & 29 & 34 \\
\hline & Educational specialisation & & & \\
\hline Journalism & 22 & 48 & 45 & 61 & 78 & 63 \\
Other communication & 9 & 17 & 11 & 7 & 9 & 10 \\
Both & 1 & 8 & 8 & 10 & 0 & 4 \\
Neither & 68 & 28 & 37 & 22 & 13 & 23 \\
\hline
\end{tabular}

Comments: Iceland $(N=187)$; Norway $(N=656)$; Finland $(N=366)$; Sweden $(N=675)$; Denmark $(N=1,362)$; Total $(N=3,246)$. Note that the percentages in different categories do not always add up to 100 due to rounding error.

\section{A typology of Nordic journalists}

Thus far, we have discussed how roles and influences vary among Nordic journalists. We have focused on the main differences (axes) and how they are generally associated with journalists' type of work, nationality, social characteristics, and so on. But how are such perceived roles and influences combined in individuals' journalistic styles? To find out, we used cluster analysis, which indicated that dividing Nordic journalists into seven groups provided the most homogenous and best internally separated clusters. We named these groups with largely similar perceived roles and influences Detached watchdogs, Entertainers, Blue-collars, Political watchdogs, Handwringers, Critical change agents, and Community engagers. Their placement is shown in Figure 4, alongside their distribution in each country. We briefly outline their main characteristics below and return to some of these results in the discussion section.

1. Detached watchdogs (18\%) emphasised the monitorial and interventionist roles' importance vis-à-vis politicians in their job but, at the same time, an objectivist stance. They also exhibit strong feelings of autonomy and a lack of outside influences on their work. They mostly comprise older and more experienced journalists but no specific beat or medium. Detached watchdogs are more common in Sweden and Denmark than the other Nordic countries.

2. Entertainers (13\%) ascribed little importance to monitorial or interventionist roles and focus on entertainment. They reported low external influences on their work. They work predominantly on entertainment, culture, sports, or health beats among national and commercial media - often, magazines or standalone online outlets. Entertainers are often freelancers, more likely female than male, and often have little experience. They are common in Norway and very rare in Denmark and Sweden. 
3. Blue-collars (12\%) felt little influence from politics but scored more highly on personal and especially procedural influences (e.g., time limits, availability of newsgathering resources). Their educational background is slightly lower than the other groups. Often, they have no specialisation in journalism. They are overrepresented in media houses' online-oriented verticals. Blue-collars are the biggest group in Iceland, but they are rare among the other Nordic countries.

4. Political watchdogs (19\%) are the most common group in the Nordic countries, alongside detached watchdogs, with whom they share a similar role orientation. However, political watchdogs reported stronger influences - especially political, but also economic and procedural. Political watchdogs can be found across newsrooms. Among specialised reporters, they are particularly common on the economy and domestic politics beats. They are more often found in Denmark than the other Nordic countries.

5. Handwringers $(12 \%)$ distinguish themselves through their strong perceived influences - particularly economic and editorial. They combine political and monitorial roles with a stronger audience orientation than the other groups. They are more likely to be women than men, tend to hold higher editorial positions with budget responsibilities (e.g., chief editors, producers), and are most common in Finland, while rare in Iceland and Norway.

6. Critical change agents' $(16 \%)$ role orientation focuses notably on political intervention and opinion (e.g., opposing government, setting agenda). They feel higher economic and procedural influences than detached watchdogs. Most common in Sweden, and rare in Iceland, critical change agents are experienced and often hold mid- or upper-level leadership positions.

7. Community engagers (10\%) reflect two distinguishing features: they mainly operate locally, and their role orientation towards political leaders is notably more positive than the other groups. Additionally, they support interventionist (developmental) roles. They feel political influences more strongly than the other groups. Community engagers are particularly numerous in Norway, but they also operate in Finland.

\section{Discussion}

In the European context, our analysis supports earlier arguments about Nordic journalists' general similarity in the roles and influences they perceive as important to their work. They typically do not emphasise the collaborative or accommodative roles' importance, reporting relative freedom from influences (see also Ahva et al., 2017). In this respect, Nordic and other Western European journalists share plenty of similarities (see also Hanitzsch et al., 2019). These findings highlight the importance of media systems' overall characteristics (Hallin \& Mancini, 2004; Brüggemann et al., 2015) in understanding journalists' everyday constraints.

Concurrently, we identified notable internal variation among answers from Nordic journalists which, for such similar countries, is unlikely to express cultural biases towards questionnaire responses (see Powers \& Vera-Zambrano, 2018). Danish and Swedish journalists stand out with high adherence to monitorial ideals. They are, generally, the most similar countries in our study. Finnish journalists differ from Danish 
and Swedish journalists most notably with their more market-oriented style. Icelandic and Norwegian journalists share Finns' populist approach, but their style is otherwise characterised by a greater distance from political influences and political roles - Iceland particularly stands out in this respect.

Many factors likely influence aggregate-level differences between the five Nordic countries. One of the most important is probably the countries' varying dominance of media types and beats. For example, Denmark has fewer local journalists than Sweden and Norway, and local journalism involves a specific character (e.g., less adversarial and more patriotic roles) and challenges from engaging with small communities (Mathisen, 2010). Another example is Swedish journalists' strong focus on monitorial roles and strong feelings of editorial autonomy. These findings likely reflect Swedish respondents' high average age (sampling differences may also have been a factor) and large proportion of political journalists. Previous research has indicated that journalists' values tend to develop early in the career and change generationally (Kantola, 2013; Wiik, 2015). For the older Swedish respondents, the monitorial approach dominated among news journalists during their formative years (Djerf-Pierre \& Weibull, 2001). Moreover, monitoring has been particularly important for political journalists, generally in their function as the "Fourth Estate", and they have also enjoyed notable freedom as representatives of journalism's "most sacred" aspect (Neveu, 2002).

There remains some uncertainty about the Nordic countries' precise placements (especially Sweden), but statistical controls seem to support our aggregate-level main findings (see Figure A11 in the Supplementary Material file for details). Icelandic journalists' distance from politics and interventionism, as well as their significant personal influences, stand out. Norwegians emerged with the most collaborative style. Finns' style was characterised by populist and interventionist tones, and they reported the greatest political and professional influences. Danish and Swedish journalists focused most on monitorial roles. Their main differences were influences: Swedes perceived economic influences most strongly, whereas Danes reported the strongest organisational influences and weakest professional and personal influences.

Interpreting all these differences is beyond the scope of this article, but we briefly address some points. To ensure that developments since data collection do not wield undue influence on our interpretations, we only consider stable characteristics and broader trends. First, our analyses corroborate earlier studies indicating that Iceland's small population generates different journalistic work conditions than the other Nordic countries - including closer personal relations between journalists and other actors (Guðmundsson \& Kristinsson, 2017; Olafsson, 2019). Second, it seems that journalism's varying and evolving relations to politics (Strömbäck et al. 2008; Skogerbø et al., 2021) and the media market (Ohlsson, 2015) in the Nordic countries influence journalistic styles nationally. Although journalists' orientations have proven resistant to changes (Wiik, 2009), recent commercialisation (e.g., Ohlsson, 2015) might have had an impact. For instance, Danish journalists' strong monitorial approach coincides with the press's recent re-politicisation (Hjarvard, 2013), due to an increasingly competitive news regime (Blach-Ørsten, 2013). In turn, Finnish journalists' populist orientation concurs with the state's heavy cuts on press subsidies (Ohlsson, 2015) and journalism's financial struggles amidst increasing media competition and technological changes since the late $2000 \mathrm{~s}$ (Nikunen, 2011; Honkonen, 2019). 
Our observations are tentative, guiding further research into Nordic journalists' professional orientations and styles. Future studies should focus on reasons for differences within and across countries to elucidate developments in Nordic journalists' professional orientations and styles. In this aim, mere surveys are insufficient; qualitative approaches are also necessary. Additionally, comparatively focusing more closely on different beat journalists' perceptions - either nationally (e.g., Väliverronen, 2018) or internationally - should complement existing national-level studies and comparative Nordic efforts such as ours. Finally, our study's survey design only focused on perceived influences' intensity. Future research could further examine different types of influences (e.g., positive, negative, coercive, persuasive) to broaden the literature's understanding of different actors and factors' impact on Nordic journalists' perceptions.

\section{Notes}

1. Eastern European countries were initially part of this analysis (which had examined up to 30 countries) but were later excluded since their markedly higher reporting on roles and influences' importance (particularly regard politics) completely dominated the analysis. In practice, this focus made discerning differences between Western European countries difficult. Given this central aim of our analysis, we excluded Eastern European countries to provide a less diverse but more relevant context for understanding Nordic journalists. For more analysis of the differences between journalists in Western and Eastern Europe, see Hanitzsch and colleagues (2019). This article's Supplementary Material file also maps an analysis of all European countries.

2. The measures have not been standardised. Standardisation is a widespread procedure in cross-cultural research, usually using within-subject or within-culture standardisation, subtracting individuals' answers to a battery of questions from the mean of their answers or of the group (typically, all answers from the same country on the same questions). Hanitzsch and colleagues (2019), for example, computed aggregated country measures for felt differences in roles and influences using mean centring. Opinions are divided, however, as to whether such standardisation alleviates cultural bias in response patterns or removes substantial variation between cultures (for a discussion, see Fischer, 2004). As we dealt with a more homogenous selection of countries, we decided not to standardise the data for fear of the latter.

3. The third and fourth axes clearly have less statistical explanatory power than the first two axes but provide further nuance. The third axis mainly discerns reporters with stronger experiences of everyday procedural influences on their work (e.g., time constraints, lack of access to information and resources, dependency on sources), which is less strong among journalists who work at non-daily newspapers and magazines (also freelancers). The fourth axis discerns rank-and-file journalists who perceive stronger political influences on their work from rank-and-file journalists who often operate in middle and upper management positions and emphasise economic and everyday constraints, as well as a need to follow journalistic codes.

4. The country variable typically explains only 5-15 per cent of answers' differences regarding roles and influences' importance. The highest proportion for roles was 22 per cent for "Provide the kind of news that attracts the largest audience", and for influences, the highest proportion was 17 per cent for "Censorship".

5. The third and fourth axes are mainly variations of the first two axes. The third axis, like the third European axis, emphasises differences in monitorial ideals and constraints (time, resources, etc.). Journalists working in culture and entertainment - and, generally, Norwegian journalists - appear to feel them less. The fourth axis particularly separates leaders at organisations who feel economic and organisational pressures at work.

\section{References}

Abbot, A. (1988). The system of professions: An essay on the division of expert labor. Chicago: University of Chicago Press.

Ahva, L., van Dalen, A., Hovden, J. F., Kolbeins, G. H., Löfgren Nilsson, M., Skovsgaard, M., \& Väliverronen, J. (2017). A welfare state of mind? Nordic journalists' conception of their role and autonomy in international context. Journalism Studies, 18(5), 595-613. https://doi.org/10.1080/1461670X.2016.1249005

Albæk, E., van Dalen, A., Pihl-Thingvad, S., Skovsgaard, M., \& de Vreese, C. (2015). Den danske journalist: Vardier, produktion, indholds [The Danish journalist: Values, production, content]. Odense: University Press of Southern Denmark. 
Asp, K. (Ed.). (2012). Svenska journalister 1989-2011 [Swedish journalists 1989-2011]. The Department of Journalism, Media and Communication, Gothenburg: University of Gothenburg.

Baker, R., Blumberg, S. J., Brick, J. M., Couper, M. P., Courtright, M., Dennis, J. M., Dillman, D., Frankel, M. R., Garland, P., Groves, R. M., Kennedy, C., Krosnick, J., Lavrakas, P. J., Lee, S., Link, M., Piekarski, L., Rao, K., Thomas, R. K., \& Zahs, D. (2010). Research synthesis: AAPOR report on online panels. Public Opinion Quarterly, 74(4), 711-781. https://doi.org/10.1093/poq/nfq048

Bergman, T., \& Strøm, K. (2011). Nordic Europe in comparative perspective. In K. Strøm \& T. Bergman (Eds.), The Madisonian turn: Political parties and parliamentary democracy in Nordic Europe (pp. 35-64). Ann Arbor: University of Michigan Press. https://doi.org/10.3998/mpub.312561

Blach-Ørsten, M. (2013). The emergence of an increasingly competitive news regime in Denmark. In R. Kuhn, \& R. Kleis-Nielsen (Eds.), Political journalism in transition: Western Europe in a comparative perspective (pp. 147-172). London: I. B. Tauris.

Bourdieu, P. (1984). Distinction: A social critique of the judgement of taste. London: Routledge \& Kegan Paul. Bourdieu, P. (1998). On television and journalism. London: Pluto Press.

Brochmann, G., Hagelund, A., Borevi, K., Vad Jønsson, H., \& Petersen, K. (2012). Immigration policy and the Scandinavian welfare state 1945-2010. Basingstoke: Palgrave Macmillan. https://doi. org/10.1057/9781137015167

Brüggemann, M., Engesser, S., Büchel, F., Humprecht, E., \& Castro, L. (2015). Hallin and Mancini revisited: Four empirical types of Western media systems. Journal of Communication, 64(6), 1037-1065. https:// doi.org/10.1111/jcom. 12127

Djerf-Pierre, M. (2007). The gender of journalism: The structure and logic of the field in the twentieth century. Nordicom Review, 28(Jubilee Issue), 81-104.

Djerf-Pierre, M., \& Weibull, L. (2001). Spegla, granska, tolka: Aktualitetsjournalistik $i$ svensk radio och TV under 1900-talet [Mirror, monitor, interpret: Current events journalism in Swedish radio and TV during the twentieth century]. Stockholm: Prisma.

Donsbach, W. (2012). Journalists' role perception. In W. Donsbach (Ed.), The international encyclopedia of communication. Wiley Online Library. https://doi.org/10.1002/9781405186407.wbiecj010.pub2

Ekecrantz, J. (2005). News paradigms, political power and cultural contexts in 20th century Sweden. In S. Høyer, \& H. Pöttker (Eds.), Diffusion of the news paradigm 1850-2000 (pp. 93-104). Gothenburg: Nordicom, University of Gothenburg.

Ettema, J. S., Whitney, D. C., \& Wackman, D. B. (1987). Professional mass communicators. In C. R. Berger, \& S. H. Chaffee (Eds.), Handbook of Communication Science (pp. 747-780). Beverley Hills, California: Sage.

Fischer, R. (2004). Standardization to account for cross-cultural response bias: A classification of score adjustment procedures and review of research in JCCP. Journal of Cross-Cultural Psychology, 35(3), 263-282. https://doi.org/10.1177/0022022104264122

Guðmundsson, B., \& Kristinsson, S. (2017). Journalistic professionalism in Iceland: A framework for analysis and an assessment. Journalism, 29(12), 1684-1703. https://doi.org/10.1177/1464884917695416

Hallin, D. C., \& Mancini, P. (2004). Comparing media systems: Three models of media and politics. Cambridge: Cambridge University Press. https://doi.org/10.1017/CBO9780511790867

Hanitzsch, T., Hanusch, F., Ramaprasad, J., \& de Beer, A. S. (Eds.). (2019). Worlds of journalism: Journalistic cultures around the globe. Reuters Institute Global Journalism Series. New York: Columbia University Press.

Hanitzsch, T., \& Örnebring, H. (2019). Professionalism, professional identity, and journalistic roles. In K. Wahl-Jorgensen, \& T. Hanitzsch (Eds.), The handbook of journalism studies (2nd ed.). (pp. 105-122). New York: Routledge. https://doi.org/10.4324/9781315167497

Hanitzsch, T., \& Vos, T. P. (2017). Journalistic roles and the struggle over institutional identity: The discursive constitution of journalism. Communication Theory, 27(2), 115-135. https://doi.org/10.1111/comt.12112

Harðarson, Ó. (2008). Media and politics in Iceland. In J. Strömbäck, M. Ørsten, \& T. Aalberg (Eds.), Communicating politics: Political communication in the Nordic countries (pp. 63-82). Gothenburg: Nordicom, University of Gothenburg.

Hjarvard, S. (2013). The mediatization of culture and society. London: Routledge. https://doi. org/10.4324/9780203155363

Honkonen, M. (2019, March 28). Yli tuhat kolmekymppistä katosi [Over a thousand thirty-somethings disappeared]. Journalisti.fi. https://www.journalisti.fi/artikkelit/2019/3/yli-tuhat-kolmekymppist-katositaantuma-teki-alalle-tulosta-vaikeaa/

Hovden, J. F. (2008). Profane and sacred: A study of the Norwegian journalistic field. Bergen: The University of Bergen.

Hovden, J. F., \& Kristensen, N. N. (2018). The cultural journalist around the globe: A comparative study of characteristics, role perceptions, and perceived influences. Journalism, 22(3), 689-708. https://doi. org/10.1177/1464884918791224 
Kananen, J. (2014). The Nordic welfare state in three eras: From emancipation to discipline. Farnham: Ashgate.

Kantola, A. (2013). From gardeners to revolutionaries: The rise of the liquid ethos in political journalism. Journalism, 14(5), 606-626. https://doi.org/10.1177/1464884912454504

Kolbeins, G. H. (2017). Country report: Journalists in Iceland. Worlds of Journalism Study. https://epub. ub.uni-muenchen.de/32014/1/Kolbeins\%2C_Gu\%C3\%B0bjoerg_Hildur_Journalists_in_Iceland.pdf

Koljonen, K. (2013). Kriisi journalismissa: Kansakunnan katastrofit ja muuttuva professio [Crisis in journalism: National catastrophes and the changing profession] [Doctoral dissertation, University of Tampere, Finland].

Linton, R. (1945). The cultural background of personality. New York: Appleton Century Crofts.

Lund, A. B., \& Berg, C. E. (2009). Denmark, Sweden and Norway television diversity by duopolistic competition and co-regulation. International Communication Gazette, 71(1-2), 19-37. https://doi. org/10.1177/1748048508097928

Mathisen, B. R. (2010). Lokaljournalistikk: Blind patriotisme eller kritisk korrektiv [Local journalism: Blind patriotism or a critical corrective]. Kristiansand, Norway: IJ-forlaget.

Maurer, P. (2019). In the grip of politics? How political journalists in France and Germany perceive political influence on their work. Journalism, 20(9), 1242-1259.

Mellado, C. (Ed.). (2021). Beyond journalistic norms: Role performance and news in comparative perspective. New York: Routledge. https://doi.org/10.4324/9780429425509

Miles, L. (Ed.). (1996). The European Union and the Nordic countries. London: Routledge. https://doi. org/10.4324/9780203991183

Moreno, J. L. (1964). Psychodrama (Vol. 1., 3rd ed.). Beacon, New York: Beacon House Inc.

Neveu, E. (2002). Four generations of political journalism. In R. Kuhn, \& E. Neveu (Eds.), Political journalism: New challenges, new practices (pp. 22-44). London: Routledge. https://doi.org/10.4324/9780203167564

Nikunen, K. (2011). Enemmän vähemmällä: Laman ja teknologisen murroksen vaikutukset suomalaisissa toimituksissa 2009-2010 [More with less: The impacts of recession and technological change in Finnish newsrooms 2009-2010]. Tampere: Tampereen yliopisto, Journalismin tutkimusyksikkö.

Nord, L. W. (2008). Comparing Nordic media systems: North between West and East? Central European Journal of Communication, 1(1), 95-110.

Ohlsson, J. (2015). The Nordic media market 2015: Nordic Media Trends, 13. Gothenburg: Nordicom, University of Gothenburg.

Olafsdottir, K., \& Olafsson, S. (2014). Economy, politics and welfare in Iceland - Booms, busts and challenges. Fafo-report 2014, NordMod 2030(sub-report 4), 13.

Olafsson, J. G. (2019). Media, democracy and small states: Political communication in Iceland [doctoral dissertation, Goldsmiths, University of London, UK].

Parsons, T. (2007). An outline of the social system. In C. Calhoun, J. Gerteis, \& J. Moody (Eds.), Classical sociological theory (pp. 421-440). Oxford: Blackwell. (Original work published 1961)

Peters, C., \& Broersma, M. J. (Eds.). (2013). Rethinking journalism: Trust and participation in a transformed news landscape. Abingdon: Routledge. https://doi.org/10.4324/9780203102688

Powers, M., \& Vera-Zambrano, S. (2018). The universal and the contextual of media systems: Research design, epistemology and the production of comparative knowledge. International Journal of Press/Politics, 23(2), 143-160. https://doi.org/10.1177/1940161218771899

Pöyhtäri, R., Väliverronen, J., \& Ahva, L. (2016). Suomalaisen toimittajan itseymmärrys muutosten keskellä [Finnish journalists' self-understanding in a time of change]. Media \& Viestintä, 39(1), 1-23. https:// doi.org/10.23983/mv.61434

Salokangas, R. (1996). Aikansa oloinen: Yleisradion historia 1949-1996 [In keeping with the times: The history of YLE 1949-1996]. Helsinki: Yleisradio.

Shoemaker, P., \& Reese, S. D. (1996). Mediating the message: Theories of influences on mass media content (2nd ed.). New York: Longman.

Skogerbø, E., Ihlen, E., Kristensen, N. N., \& Nord, L. (Eds.). (2021). Power, communication, and politics in the Nordic countries. Gothenburg: Nordicom, University of Gothenburg. https://doi. org/10.48335/9789188855299

Skovsgaard, M., \& van Dalen, A. (2013). The fading public voice: The polarizing effect of commercialization on political and other beats and its democratic consequences. Journalism Studies, 14(3), 371-386. https:// doi.org/10.1080/1461670X.2012.701905

Strøm, K., \& Bergman, T. (Eds.). (2011). The Madisonian turn: Political parties and parliamentary democracy in Nordic Europe. Ann Arbor, Michigan: Michigan University Press.

Strömbäck, J., Ørsten, M., \& Aalberg, T. A. (Eds.) (2008). Communicating politics: Political communication in the Nordic countries. Gothenburg: Nordicom, University of Gothenburg. 
Syvertsen, T., Moe, H., Enli, G., \& Mjøs, O. J. (2014). The media welfare state: Nordic media in the digital era. Ann Arbor, Michigan: University of Michigan Press.

van Dalen, A. (2012). The people behind the political headlines: A comparison of political journalists in Denmark, Germany, the United Kingdom and Spain. International Communication Gazette, 74(5), 464-483. https://doi.org/10.1177/1748048512445154

Väliverronen, J. (2018). More of the same or a different breed altogether? A national comparison of role perceptions and ethical stances among Finnish political journalists. Nordicom Review, 39(1), 51-66. https://doi.org/10.2478/nor-2018-0001

Weaver, D. (Ed.) (1998). The global journalist: News people around the world. Cresskill, New Jersey: Hampton Press.

Weaver, D. H., \& Wilhoit, G. C. (1986). The American journalist: A portrait of U.S. news people and their work. Bloomington, Indiana: Indiana University Press.

Weaver, D. H., \& Wilhoit, G. C. (1996). The American journalist in the 1990s: US news people at the end of an era. Mahwah, New Jersey: Erlbaum.

Weaver, D. H., \& Willnat, L. (Eds.). (2012). The global journalist in the 21st century. New York: Routledge. https://doi.org/10.4324/9780203148679

Weber, M. (1978). Economy and society. Berkeley, California: University of California Press.

Wiik, J. (2009). Identities under construction: Professional journalism in a phase of destabilization. International Review of Sociology, 19(2), 351-365. https://doi.org/10.1080/03906700902833676

Wiik, J. (2015). Internal boundaries: The stratification of the journalistic collective. In M. Carlson, \& S. C. Lewis (Eds.), Boundaries of journalism: Professionalism, practices and participation (pp. 118-134). London: Routledge. https://doi.org/10.4324/9781315727684

(C) 2021 Nordicom and respective authors. This is an Open Access work licensed under the terms of the Creative Commons Attribution-NonCommercial-NoDerivatives 4.0 International Public licence (CC BY-NC-ND 4.0). To view a copy of the licence, visit https://creativecommons.org/ licenses/by-nc-nd/4.0/ 